\title{
A LANDSCAPE APPROACH TO ASPEN RESTORATION: Understanding THE Role OF BIOPHYSicAl SETTING In ASPen COMMUnity DYNAMICS
}

\author{
KATHRYN BROWN ANDREW J. HANSEN \\ ECOLOGY DEPARTMENT $\downarrow$ MONTANA STATE UNIVERSITY \\ BOZEMAN
}

\begin{abstract}
$\uparrow \quad$ BACKGROUND AND OBJECTIVES
The aim of this study is to better understand the relationship of biotic and abiotic variables to the distribution, performance, and rates of loss of aspen in the Greater Yellowstone Ecosystem. Aspen communities, though critically important for maintaining biodiversity, soil quality, and nutrient cycling, are declining rapidly in the Northern Rockies. Fire suppression, elk browsing, and climatic change are the most widely advanced explanations for this widespread loss of aspen. The role of biophysical factors (e.g. topography, climate, soils, and competing vegetation) in determining aspen performance, however, is poorly understood. Knowledge of these relationships may provide a basis for tailoring aspen restoration efforts to specific landscape settings. To better understand the influence of biophysical variables on aspen dynamics, this study addresses three hypotheses:
\end{abstract}

1. The aerial distribution of aspen is not random across the landscape and varies as a function of biophysical setting.

2. Within its distribution, growth rates and productivity of aspen stands differ relative to biotic and abiotic variables.

3. Rates of aspen loss in the landscape differ relative to biophysical setting.

Here we report progress on the first year of the twoyear study.

\section{$\uparrow \quad$ METHODS}

The study area is the Greater Yellowstone Ecosystem from a southern boundary near Jackson, Wyoming to the Crazy Mountains north of Bozeman, Montana (Figure 1). The study area includes areas of the Gallatin National Forest, Targhee National Forest, Bridger-Teton National Forest, Yellowstone National Park and Teton National Park. Analysis to date is restricted to the Gallatin National Forest and Yellowstone National Park.

For preliminary analysis of its aerial distribution, we mapped aspen across the study area (currently Gallatin NF and Yellowstone) and used classification and regression tree (CART) analysis to examine the relationship between environmental variables and aspen distribution.

Aspen distribution within the study area was obtained through a combination of GIS data layers. We mapped aspen from random aerial photograph transects placed throughout the study area to sample across elevations, major aspect, and parent material types. We then combined our map with aspen maps derived from the Gallatin National Forest stand cover map and the Yellowstone National Park cover-type map. (Table1). The predictor data used for this analysis were elevation, slope angle, aspect, and soil parent material. Topographic data were from a DEM and parent material data reclassified from SSURGO data. (Table2). 


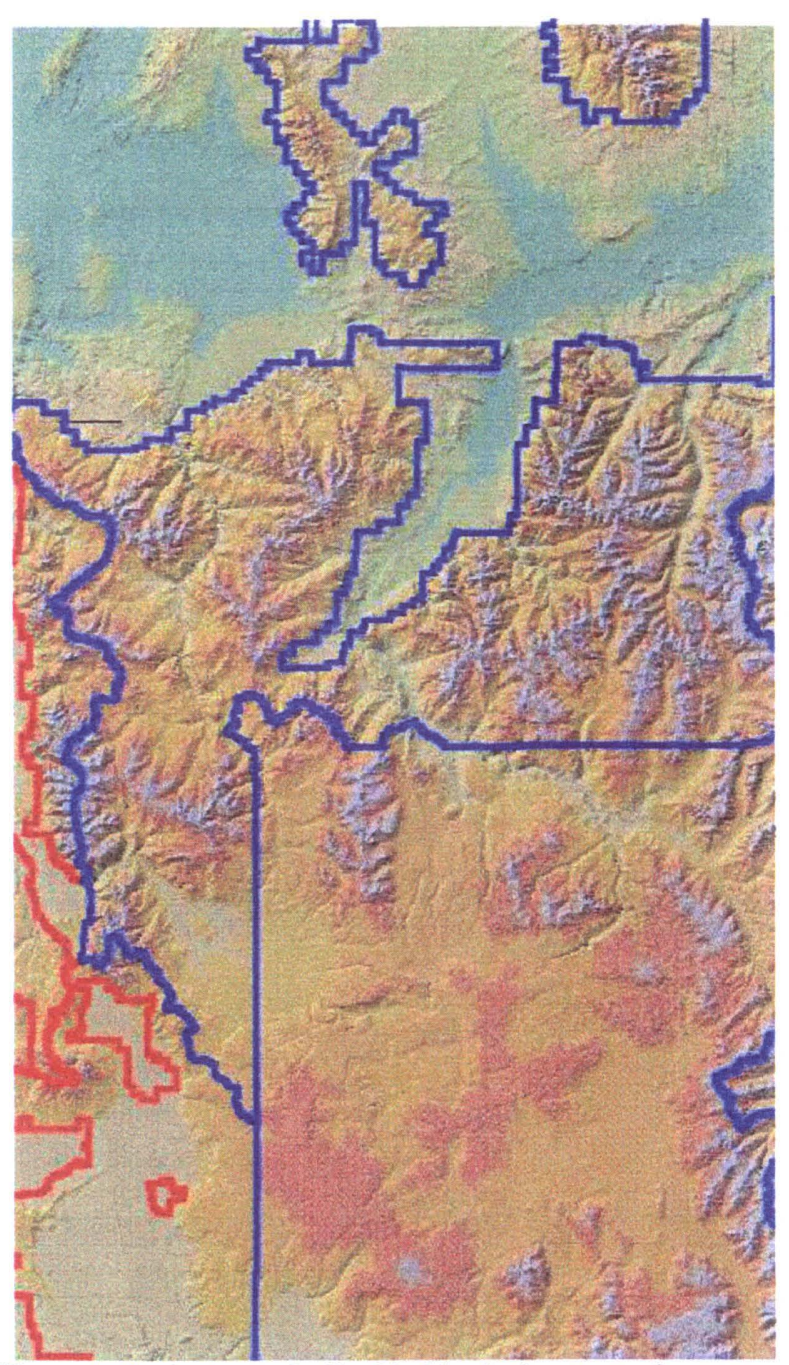

Figure 1. Study Area: Outlined in blue is the extent of current analysis, outlined in red are boundaries of public lands to be included in future analysis.

\begin{tabular}{|c|c|c|c|}
\hline $\begin{array}{l}\begin{array}{l}\text { Dataset } \\
\text { (source) }\end{array} \\
\end{array}$ & Resolution & Extent & Combined \\
\hline $\begin{array}{l}\text { Air-photo } \\
\text { transects } \\
\text { digitized }\end{array}$ & $\begin{array}{l}\text { shapefile- }>30-\mathrm{m} \\
\text { grid }\end{array}$ & $\begin{array}{l}\text { so far: } \\
\text { GNF \& } \\
\text { YNP along } \\
\text { random } \\
\text { transects } \\
\text { plan: } \\
\text { include } \\
\text { TNF, B-T, } \\
\text { \& GTNP }\end{array}$ & \multirow[t]{4}{*}{$\begin{array}{l}\text { each } 30-\mathrm{m} \text { grid was } \\
\text { converted to a grid } \\
\text { coded } 1=\text { Aspen } \\
0=\text { other and } \\
\text { combined. } \\
\text { this } 30-\mathrm{m} \text { grid was } \\
\text { converted to a } 100- \\
\text { m grid for analysis. }\end{array}$} \\
\hline $\begin{array}{l}\text { GNF stand } \\
\text { map }\end{array}$ & 30-m grid & $\overline{G N F}$ & \\
\hline $\begin{array}{l}\text { YNP cover- } \\
\text { type map }\end{array}$ & $\begin{array}{l}\text { shapefile }->30-\mathrm{m} \\
\text { grid }\end{array}$ & YNP & \\
\hline $\begin{array}{l}\text { TNF, B-T, } \\
\text { and GTNP } \\
\text { maps }\end{array}$ & 2-ha & $?$ & \\
\hline
\end{tabular}

\begin{tabular}{|c|c|c|}
\hline Dataset (source) & Resolution & Extent \\
\hline $\begin{array}{l}\text { Elevation from DEM } \\
\text { (from USGS) }\end{array}$ & $\begin{array}{l}30-m \text { DEM }>100-m \\
\text { DEM }\end{array}$ & GYE \\
\hline Aspect from DEM & $\begin{array}{l}\text { 30-m DEM }->100-\mathrm{m} \\
\text { DEM } \rightarrow 100-\mathrm{m} \text { Aspect } \\
\text { grid }\end{array}$ & GYE \\
\hline Slope angle from DEM & $\begin{array}{l}\text { 30-m DEM }->100-\mathrm{m} \\
\text { DEM-> 100-m Slope } \\
\text { angle grid }\end{array}$ & GYE \\
\hline $\begin{array}{l}\text { Parent material } \\
\text { (SSURGO reclassified } \\
\text { by Andrea Wright) }\end{array}$ & $\begin{array}{l}\text { shapefile- }>30-\mathrm{m} \text { grid }-> \\
100-\mathrm{m} \text { grid }\end{array}$ & GYE \\
\hline $\begin{array}{l}\text { better parent material, } \\
\text { soil texture, soil clay } \\
\text { content, total soil } \\
\text { carbon, nitrogen }\end{array}$ & talk to Henry Shovik & $\begin{array}{l}\text { should be } \\
\text { GYE -wide }\end{array}$ \\
\hline $\begin{array}{l}\text { Climatic } \\
\text { (annual and monthly } \\
\text { temperature, growing- } \\
\text { degree days, and } \\
\text { precipitation from } \\
\text { DAYMET) }\end{array}$ & 1,000-m grid & $\begin{array}{l}\text { we have } \\
\text { GYE } \\
\text { coverage-- } \\
\text { modeled } \\
\text { nationally; } \\
\text { still checking } \\
\text { on accuracy, } \\
\text { utility to this } \\
\text { study }\end{array}$ \\
\hline
\end{tabular}

Using random samples stratified by each of the predictor variables, we developed a classification tree with class membership defined as "aspen" or "other". The tree was then used to predict the membership of hold-out observations and the percentage of correctly classified observations was calculated. We mapped the CART model across the study area for a visual comparison of mapped and predicted aspen distribution.

Aspen performance relative to biophysical setting is being examined through field measurement of aspen stand structure, composition and growth rates. Field sites were selected from maps of aspen distribution and stratified by elevation and major aspect. For the 2001 field season, field sampling focused on the Gallatin National Forest and Yellowstone National Park. Using a nested, circular plot design, we measured tree density by species and dbh class, seedling/sapling density, herbaceous biomass, shrub density, canopy cover, snag density, course woody debris, and took increment cores from aspen trees of each dbh class represented on a site.

We sampled 47 sites during the 2001 field season (see Table 3 for sample sizes for each stratum). We used BIOPAK software to calculate total above-ground biomass estimates from the mid- 
range of the basal diameter class for shrubs. Many of the equations BIOPAK uses to calculate tree aboveground biomass estimates require $\mathrm{dbh}$ and height measurements; we used functions derived from a previous study (Hansen et al. 2000) to estimate height at the mid-range of each dbh-class for all tree species except aspen. We fit a negative exponential function to measured dbh and height data for aspen and used this relationship to estimate height at the mid-range of each dbh class. We then calculated total aboveground biomass for the mid-range dbh of each $\mathrm{dbh}$ class for trees and multiplied this by density to estimate tree biomass by species at each site. We will use increment cores to measure average annual diameter increment for aspen and subtract from current dbh to estimate dbh for the previous year. The old dbh and height will be used to calculate the total aboveground biomass of the previous year. Previous biomass will be subtracted from current biomass to estimate annual change in biomass for aspen. This will then be regressed against predictor abiotic (topography, soils, climate) and biotic (herbaceous biomass, shrub biomass, and tree biomass by species) variables to examine any relationships between aspen annual net productivity and biophysical environment.

\section{$\downarrow \quad$ PREliminary ReSUlts}

Elevation explained the largest proportion of the variance in aspen distribution in the CART model. The model had a high producer's accuracy-for pixels known to be aspen it predicted aspen $91.2 \%$ of the time and for pixels known to be other it predicted other $76.9 \%$ of the time. However, the map of the CART model showed that it highly overpredicts the occurrence of aspen in the landscape. Much more of the study area is predicted to be aspen than maps of aspen distribution show. The current CART model does not account for competitive interaction, existing vegetation, or climatic variables. The areas the model predicts as aspen tend to be intermediate elevations, slopes between three and twenty degrees, and in the model aspen avoids rhyolitic soils. The CART model needs to be improved. We plan to add climatic predictors such as annual average temperature, precipitation, and growing-degree days and more specific soils variables such as texture, water holding capacity, silt/clay content, and total carbon/nitrogen content.

Analysis of field data on aspen performance is in the preliminary stages. We report here the preliminary analysis of distribution of biomass for aspen stands. These are reported by tree species. We do not expect biomass to necessarily vary with biophysical setting because biomass reflects both growth rates and removal rates. While we hypothesize that growth rates vary with biophysical setting, we make no predictions about the spatial configuration of removal through disturbance, herbivory, or decomposition.

Current data show a fairly uniform distribution of mean aspen biomass across aspects and from 1700-2300 meters in elevation; however, mean aspen biomass does appear to be depressed where mean biomass of Douglas fir is particularly high. (Appendix A) T otal biomass for herbaceous plants, shrubs, and trees also appears fairly uniform in distribution across aspects except for southeastfacing slopes which show a marked spike in shrub biomass. Total biomass for herbaceous plants, shrubs, and trees is highest at intermediate elevations ( 1900-2200 meters).

\section{Tasks for Year Two}

The response variable of interest, annual above-ground net primary productivity for aspen, has yet to be calculated as we complete increment core analysis. A second season of fieldwork and increased sample sizes (especially at low and high elevations and on east and west aspects --see Table 3) will be necessary before a more complete analysis can be made.

\begin{tabular}{|l|l|l|}
\hline Table 3. Sample sizes of field sites by stratum. \\
\hline \hline \multirow{2}{*}{ Elevation Class } & Aspect & $\begin{array}{l}\text { Number of Plots } \\
\text { Sampled }\end{array}$ \\
\hline 1501-1800 meters & North & 0 \\
\cline { 2 - 3 } & East & 1 \\
\cline { 2 - 3 } & South & 1 \\
\cline { 2 - 3 } & West & 1 \\
\cline { 2 - 3 } & Flat & 1 \\
\hline $1801-2000$ meters & North & 12 \\
\cline { 2 - 3 } & East & 1 \\
\cline { 2 - 3 } & South & 4 \\
\cline { 2 - 3 } & West & 1 \\
\cline { 2 - 3 } & Flat & 7 \\
\hline $2001+$ meters & North & 2 \\
\cline { 2 - 3 } & East & 2 \\
\cline { 2 - 3 } & South & 10 \\
\cline { 2 - 3 } & West & 4 \\
\cline { 2 - 3 } & Flat & 0 \\
\hline Total & & 47 \\
\hline
\end{tabular}


Data collection planned for Year Two is as follows.

- Aspen distribution:

- Expand study area (maps of aspen distribution) to include the BridgerTeton National Forest, Targhee National Forest, and Grand Teton National Park

- Add predictor data: climatic and soils, see Table 2.

- Aspen growth rates and performance:

- Complete increment core analysis to get growth rates and estimates of change in aspen biomass and regress against topographic, soils, climatic variables and against biomass of other plant components.

- Increase sample size through summer field work and expand to sample in the southern end of the ecosystem (BridgerTeton, Targhee, Teton).

- Add predictor data (see above).

- Rates of loss in the landscape:

- Planned for fall 2002:

- Map change in aspen cover from 19502000 aerial photographs.

- Quantify aspen cover at several timesteps through point-intercept method.

- Generate maps of change in aspen cover and regress rate of loss versus predictor variables.

\section{LITERATURE CITED:}

Hansen, A.J., J.J. Rotella, M.P.V. Kraska and D. Brown. 2000. Spatial patterns of primary productivity in the Greater Yellowstone Ecosystem. Landscape Ecology 15: 505522.

\section{ACKNOWLEDGEMENTS}

We thank Dr. Robert E. Keane, USFS Rocky Mountain Research Station; Roy Renkin, Yellowstone National Park, Center for Resources; Dr. Don Despain, USGS-BRD; Julie Shea, Gallatin National Forest; and Dr. Henry Shovik, Gallatin National Forest for providing comments, advice, and knowledge of data. Steve Swain and Jackie Riley of the Gallatin National Forest provided access to the Gallatin National Forest stand map and aerial photographs; Roy Renkin provided access to Yellowstone National Park aerial photographs. John Varley, Roy Renkin, and Christie Hendrix granted permission to work in Yellowstone National Park. Financial support was provided by the University of Wyoming-National Park Service Research Unit, USFS Rocky Mountain Research Station Fire Sciences Laboratory, and Yellowstone National Park Cooperative Ecosystems Studies Unit. 


\section{APPENDIX A}
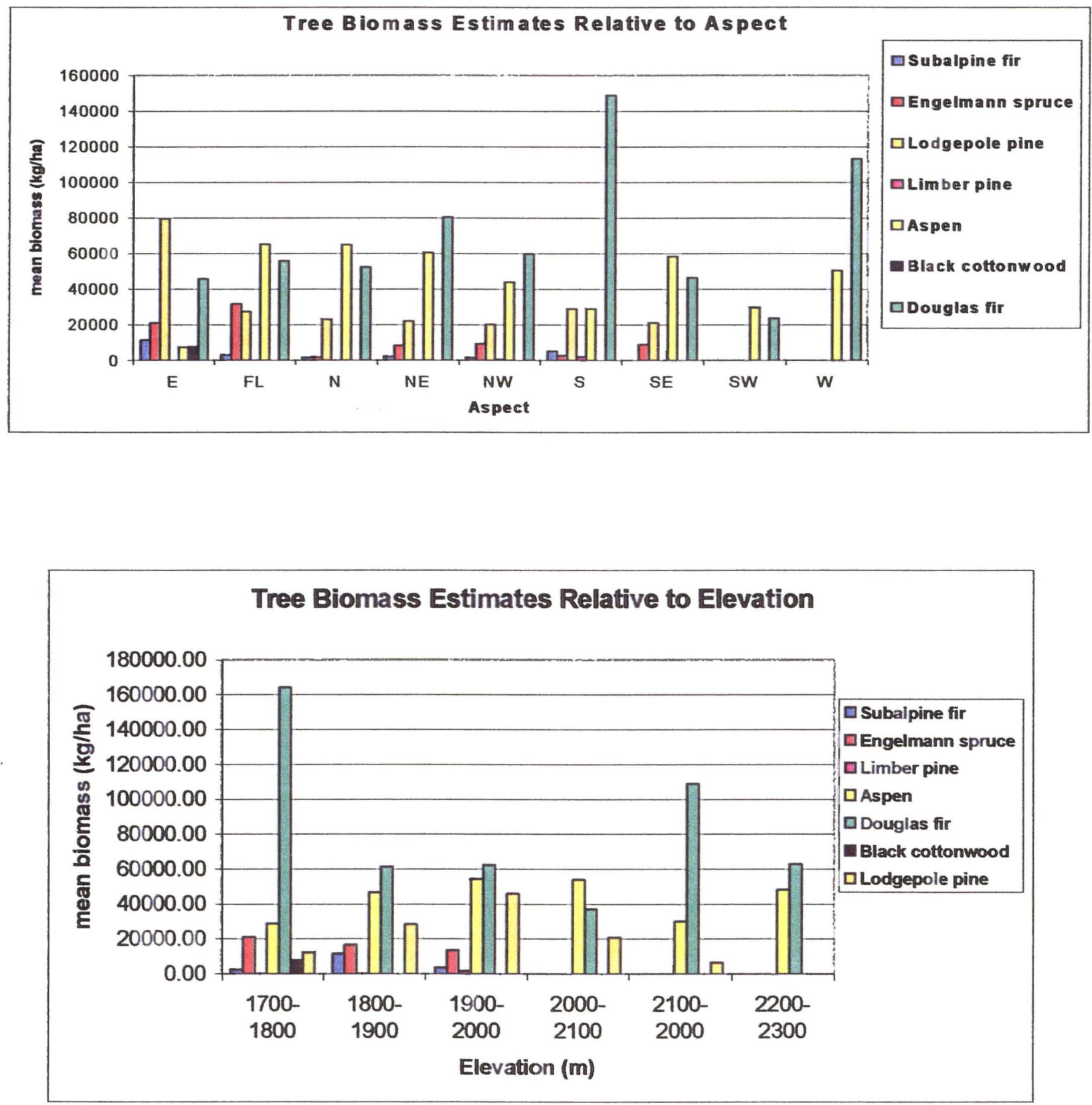